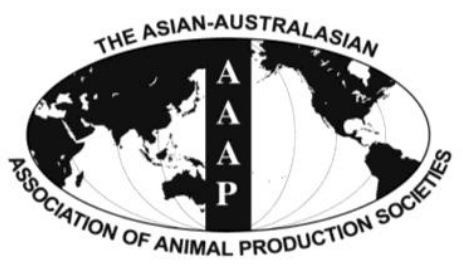

\title{
Effects of Supplemental Beta-mannanase on Digestible Energy and Metabolizable Energy Contents of Copra Expellers and Palm Kernel Expellers Fed to Pigs
}

\author{
W. B. Kwon and B. G. Kim* \\ Department of Animal Science and Technology, Konkuk University, Seoul 143-701, Korea
}

\begin{abstract}
The purpose of this study was to determine the effect of $\beta$-mannanase supplementation on digestible energy (DE) and metabolizable energy (ME) contents of copra expellers (CE) and palm kernel expellers (PKE) fed to pigs. Six barrows with an initial body weight of $38.0 \mathrm{~kg}$ (standard deviation $=1.5$ ) were randomly allotted to a $6 \times 6$ Latin square design with 6 dietary treatments and 6 periods. Six experimental diets were prepared in a $3 \times 2$ factorial treatment arrangement with 3 diets of a corn-soybean meal-based diet, a CE $30 \%$ diet, and a PKE $30 \%$ diet and with 2 concentrations of supplemental $\beta$-mannanase at 0 or $2,400 \mathrm{U} / \mathrm{kg}$. All diets had the same proportion of corn:soybean meal ratio at 2.88:1. The marker-to-marker procedure was used for fecal and urine collection with 4-d adaptation and 5-d collection periods. No interactive effects were observed between diet and $\beta$-mannanase on energy digestibility and $\mathrm{DE}$ and ME contents of experimental diets. However, diets containing CE or PKE had less ( $\mathrm{p}<0.05)$ DE and ME contents compared with the corn-soybean meal-based diet. The DE and ME contents in CE and PKE were not affected by supplemental $\beta$-mannanase. Taken together, we failed to find the effect of $\beta$-mannanase supplementation on energy utilization in CE and PKE fed to pigs. (Key Words: Energy Utilization, $\beta$-Mannanase, Copra Expellers, Palm Kernel Expellers, Swine)
\end{abstract}

\section{INTRODUCTION}

Sharp increases in the prices of traditional feedstuffs such as corn and soybean meal (SBM) have feed producers seeking alternatives to traditional feed ingredients in swine diets. Copra expellers (CE) and palm kernel expellers (PKE), co-products from vegetable oil industry, are produced by the mechanical oil extraction from dried coconut kernels and palm nut kernels, respectively (Son et al., 2012; Sulabo et al., 2013). These co-products can be good candidates for alternative feedstuffs because of the relatively low price and fairly good nutrient composition compared with corn and SBM (Agunbiade et al., 1999; Kim et al., 2001). However, the high concentration of non-starch polysaccharides (NSP) such as mannan in CE and PKE (Table 1) can limit the use of these ingredients in swine

* Corresponding Author: B. G. Kim. Tel: +82-2-2049-6255, Fax: +82-2-446-6255, E-mail: bgkim@konkuk.ac.kr

Submitted Mar. 28, 2015; Revised Apr. 20, 2015; Accepted Apr. 25, 2015 diets. Previous studies have shown that utilization of carbohydrates and protein retention were hindered by mannan in swine diets (Kratzer et al., 1964; Rainbird et al., 1984).

Supplemental NSP-degrading enzymes have been reported to improve nutrient digestibility in swine diets (Yin et al., 2000; 2001). Beta-mannanase is one of NSPdegrading enzymes that hydrolyze mannan in feedstuffs (McCleary, 1988). A recent study indicated that supplemental $\beta$-mannanase improves dry matter (DM), organic matter, and energy digestibility in PKE-containing diets fed to growing pigs (Mok et al., 2013). A previous study also reported an increase in the ME content and a nutrient digestibility improvement of copra meal treated by $\beta$-mannanase in broiler diets (Khanongnuch et al., 2006). The results of these studies indicate that the efficiency of nutrient digestibility will be increased when $\beta$-mannanase is added to CE- or PKE-containing swine diets. However, data on the effect of $\beta$-mannanase supplementation on energy digestibility of CE- or PKE-containing diets are rare. There 
Table 1. Energy and nutrient composition of corn, soybean meal (SBM), copra expellers (CE), and palm kernel expellers (PKE), as-is basis

\begin{tabular}{lcccc}
\hline \multirow{2}{*}{ Item } & \multicolumn{4}{c}{ Ingredient } \\
\cline { 2 - 5 } & Corn & SBM & CE & PKE \\
\hline Dry matter (\%) & 86.3 & 87.3 & 88.7 & 92.6 \\
Gross energy (kcal/kg) & 3,958 & 4,251 & 4,214 & 4,417 \\
Crude protein (\%) & 6.9 & 46.9 & 21.0 & 16.9 \\
Ether extract (\%) & 3.45 & 1.14 & 7.46 & 6.74 \\
Crude fiber (\%) & 2.27 & 4.19 & 9.22 & 12.5 \\
Ash (\%) & 1.43 & 6.12 & 6.71 & 4.02 \\
Calcium (\%) & 0.04 & 0.23 & 0.11 & 0.28 \\
Phosphorus (\%) & 0.28 & 0.63 & 0.55 & 0.66 \\
Neutral detergent fiber (\%) & 19.7 & 31.4 & 54.5 & 68.3 \\
Acid detergent fiber (\%) & 2.92 & 6.52 & 27.4 & 37.7 \\
Mannan (\%) & 0.29 & 1.20 & 24.6 & 31.3 \\
\hline
\end{tabular}

is also a lack of information on the effect of $\beta$-mannanase supplementation on digestible energy (DE) and metabolizable energy (ME) contents of CE and PKE. Therefore, the objective of present study was to determine the effect of supplemental $\beta$-mannanase on the DE and ME contents of $\mathrm{CE}$ and PKE fed to pigs.

\section{MATERIALS AND METHODS}

\section{Animal care}

The experimental procedure was approved by the Institutional Animal Care and Use Committee at Konkuk University.

\section{Animal, diet and feeding}

Six crossbred barrows with an initial body weight of $38.0 \mathrm{~kg}$ (standard deviation $=1.5$ ) were used to measure the effect of supplemental $\beta$-mannanase on the DE and ME contents of CE and PKE fed to pigs. Animals were allotted to a $6 \times 6$ Latin square design with 6 dietary treatments and 6 periods (Kim and Kim, 2010). Pigs were individually housed in metabolism crates that were equipped with a feeder and a nipple drinker.

Six experimental diets were prepared in a $3 \times 2$ factorial treatment arrangement. There were 3 types of diets (cornSBM-based diet, CE 30\% diet, and PKE 30\% diet) and 2 concentrations of supplemental $\beta$-mannanase ( 0 and 2,400 $\mathrm{U} / \mathrm{kg}$ ). The energy and nutrient composition of corn, SBM, CE, and PKE are presented in Table 1. A basal diet based on corn and SBM was formulated (Table 2). Two additional diets were formulated by including $30 \%$ of CE and PKE to the basal diet at the expense of corn and SBM. All diets contained the same proportion of corn:SBM ratio at 2.88:1. A supplemental enzyme, $\beta$-mannanase, was added to the 3 different diets at the expense of $\beta$-mannanase carrier. Vitamins and minerals were included in all diets to meet or exceed nutrient requirement estimates (NRC, 2012).

The amount of feed provided daily per pig was approximately 3 times the estimated requirement for maintenance (i.e., $197 \mathrm{kcal}$ of $\mathrm{ME} / \mathrm{kg}$ of body weight ${ }^{0.60}$; Kil et al., 2013). The daily feed allowance divided into 2 equal meals, and fed to pigs at 0800 and 1600. The feed allowance for each pig was adjusted based on the body weight of pigs at the beginning of each period. Water was

Table 2. Ingredient composition of experimental diets, as-fed basis

\begin{tabular}{|c|c|c|c|c|c|c|}
\hline \multirow{3}{*}{ Items } & \multicolumn{6}{|c|}{$\beta$-Mannanase $(\mathrm{U} / \mathrm{kg})$} \\
\hline & \multicolumn{2}{|c|}{ Corn-SBM } & \multicolumn{2}{|c|}{$\mathrm{CE}$} & \multicolumn{2}{|c|}{ PKE } \\
\hline & 0 & 2,400 & 0 & 2,400 & 0 & 2,400 \\
\hline \multicolumn{7}{|l|}{ Ingredient $(\%)$} \\
\hline Ground corn & 72.00 & 72.00 & 49.73 & 49.73 & 49.73 & 49.73 \\
\hline Soybean meal, $48 \%$ crude protein & 25.00 & 25.00 & 17.27 & 17.27 & 17.27 & 17.27 \\
\hline Copra expellers & - & - & 30.00 & 30.00 & - & - \\
\hline Palm kernel expellers & - & - & - & - & 30.00 & 30.00 \\
\hline$\beta$-Mannanase & - & 0.30 & - & 0.30 & - & 0.30 \\
\hline$\beta$-Mannanase carrier & 0.30 & - & 0.30 & - & 0.30 & - \\
\hline Ground limestone & 1.00 & 1.00 & 1.00 & 1.00 & 1.00 & 1.00 \\
\hline Dicalcium phosphate & 0.80 & 0.80 & 0.80 & 0.80 & 0.80 & 0.80 \\
\hline Salt & 0.40 & 0.40 & 0.40 & 0.40 & 0.40 & 0.40 \\
\hline Vitamin-mineral premix $^{1}$ & 0.50 & 0.50 & 0.50 & 0.50 & 0.50 & 0.50 \\
\hline \multicolumn{7}{|l|}{ Analyzed composition } \\
\hline Gross energy (kcal/kg) & 3,895 & 3,946 & 3,958 & 3.969 & 4,043 & 4,049 \\
\hline Mannan (\%) & 0.44 & 0.83 & 3.90 & 3.61 & 2.14 & 3.39 \\
\hline
\end{tabular}

Corn-SBM, corn-soybean meal-based diet; CE, copra expellers 30\% diet; PKE, palm kernel expellers 30\% diet.

${ }^{1}$ Provided per kg of diet: vitamin A, 11,128 IU; vitamin $\mathrm{D}_{3}$, 2,204 IU; vitamin E, $66 \mathrm{IU}$; vitamin $\mathrm{K}, 1.42 \mathrm{mg}$; thiamin, $0.24 \mathrm{mg}$; riboflavin, $6.58 \mathrm{mg}$; pyridoxine, $0.24 \mathrm{mg}$; vitamin $\mathrm{B}_{12}, 0.03 \mathrm{mg}$; D-pantothenic acid, $23.5 \mathrm{mg}$; niacin, $44 \mathrm{mg}$; folic acid, $1.58 \mathrm{mg}$; biotin, $0.44 \mathrm{mg}$; Cu, $10 \mathrm{mg}$ as copper sulfate; Fe, $125 \mathrm{mg}$ as iron sulfate; I, $1.26 \mathrm{mg}$ as potassium iodate; Mn, $60 \mathrm{mg}$ as manganese sulfate; Se, $0.3 \mathrm{mg}$ as sodium selenite; $\mathrm{Zn}$, $100 \mathrm{mg}$ as zinc oxide. 
freely accessible at all times.

\section{Sample collection}

An experimental period consisted of 4-d adaptation and 5-d collection periods. Feces were collected according to the marker-to-marker procedure (Kong and Adeola, 2014) using chromic oxide $\left(\mathrm{Cr}_{2} \mathrm{O}_{3}\right)$ as an indigestible marker. Chromic oxide was added to the morning diets on $\mathrm{d} 5$ and 10. Urine was collected from 1400 on $\mathrm{d} 5$ to 1400 on d 10 with $200 \mathrm{~mL}$ of $3 \mathrm{~N} \mathrm{HCl}$ for reducing ammonia loss and limiting microbial activity. The total quantity of feces and approximately $200 \mathrm{~mL}$ of sub-sampled urine were immediately stored at $-20^{\circ} \mathrm{C}$ after collection.

\section{Chemical analysis}

Fecal samples were dried in a forced-air drying oven at $55^{\circ} \mathrm{C}$ and ground before analysis. The diets, feces and urine were analyzed for gross energy (GE) using a bomb calorimeter (Parr 1261; Parr Instruments Co., Moline, IL, USA). To analyze DM in the ingredients, diets, and feces, all samples were dried in the forced-air drying oven at $135^{\circ} \mathrm{C}$ for $2 \mathrm{~h}$ (method 930.15; AOAC, 2005). Ingredient samples were also analyzed for crude protein (method 984.13; AOAC, 2005), ether extract (method 920.39; AOAC, 2005), and crude fiber (method 978.10; AOAC, 2005). Ingredient samples were analyzed for ash (method 942.05; AOAC, 2005), calcium (method 968.08; AOAC, 2005), phosphorus (method 964.06; AOAC, 2005) neutral detergent fiber (method 2002.04; AOAC, 2005), and acid detergent fiber (method 973.18; AOAC, 2005). Diets and ingredient samples were also analyzed for the mannan concentration. Briefly, the samples were hydrolyzed using $72 \%$ (w/w) $\mathrm{H}_{2} \mathrm{SO}_{4}$ for $1 \mathrm{~h}$. Then, the samples were diluted with distilled water to $\mathrm{H}_{2} \mathrm{SO}_{4}$ concentration $1 \mathrm{~N}$ and incubated at $121^{\circ} \mathrm{C}$ for $45 \mathrm{~min}$. The mannan contents in hydrolysates were determined using an evaporative light scattering detector and a Shodex sugar column SP0810 (8.0 mm×300 mm; Showa Denko K.K., Tokyo, Japan).

\section{Calculations and statistical analysis}

The DE and ME values in experimental diets and ingredients were calculated by the method for difference procedure described by Kong and Adeola (2014). Data were analyzed using the GLM procedure of SAS (SAS Institute Inc., Cary, NC, USA). The model included diet, $\beta$ mannanase and the interaction between diet and $\beta$ mannanase as fixed variables and animal and period as random variables. The experimental unit was a pig, and the statistical significance was determined at an alpha of 0.05 .

\section{RESULTS}

All animals were healthy and easily consumed the provided feed throughout the experimental period. The interactive effect between diet and $\beta$-mannanase was not observed in energy digestibility, DE and ME values of the experimental diets (Table 3 ). There was also no effect of $\beta$ mannanase supplementation, but there was a diet effect on energy digestibility, $\mathrm{DE}$ and $\mathrm{ME}$ contents of the experimental diets $(\mathrm{p}<0.001)$. The energy digestibility was greater $(\mathrm{p}<0.05)$ in the basal diet than in the CE- or PKEcontaining diet. The basal diet also had a greater $(p<0.05)$ DE content than a CE $30 \%$ diet or a PKE $30 \%$ diet $(3,365$ vs 3,187 and $3,188 \mathrm{kcal} / \mathrm{kg}$ on an as-fed basis). As the urinary energy output did not differ among the diets, the ME content in the basal diet was also greater $(\mathrm{p}<0.05)$ than in a CE $30 \%$ or a PKE $30 \%$ diet (3,251 vs 3,082 and 3,068 $\mathrm{kcal} / \mathrm{kg}$ on an as-fed basis).

No effect of $\beta$-mannanase supplementation in DE and ME values of CE and PKE were observed (Table 4). When calculated on an as-fed basis, the DE and ME contents in CE $(2,876$ and $2,787 \mathrm{kcal} / \mathrm{kg}$, respectively $)$ were

Table 3. Effects of supplemental $\beta$-mannanase on digestibility of corn-soybean meal-, copra expellers-, or palm kernel expellers-based diets fed to pig $^{1,2}$

\begin{tabular}{|c|c|c|c|c|c|c|c|c|c|c|}
\hline \multirow{3}{*}{ Items } & \multicolumn{6}{|c|}{$\beta$-Mannanase $(\mathrm{U} / \mathrm{kg})$} & \multirow{3}{*}{ RMSE } & \multirow{2}{*}{\multicolumn{3}{|c|}{ p-value }} \\
\hline & \multicolumn{2}{|c|}{ Corn-SBM } & \multicolumn{2}{|c|}{$\mathrm{CE}$} & \multicolumn{2}{|c|}{ PKE } & & & & \\
\hline & 0 & 2,400 & 0 & 2,400 & 0 & 2,400 & & Diet & Enzyme & Dietxenzyme \\
\hline Feed intake $(\mathrm{kg} / 5 \mathrm{~d})$ & 8.77 & 8.84 & 8.94 & 9.02 & 8.89 & 8.89 & 1.35 & 0.949 & 0.911 & 1.000 \\
\hline GE intake (Mcal/5 d) & 34.1 & 34.9 & 35.4 & 35.8 & 35.9 & 36.0 & 5.4 & 0.790 & 0.824 & 0.988 \\
\hline Fecal GE output (Mcal/5 d) & 4.77 & 4.93 & 6.95 & 6.89 & 7.59 & 7.59 & 0.81 & $<0.001$ & 0.891 & 0.945 \\
\hline Energy digestibility (\%) & 86.0 & 85.7 & 80.2 & 80.6 & 78.7 & 78.8 & 1.7 & $<0.001$ & 0.858 & 0.900 \\
\hline $\mathrm{DE}$ in diet $(\mathrm{kcal} / \mathrm{kg})$ & 3,347 & 3,383 & 3,174 & 3,200 & 3,184 & 3,192 & 70 & $<0.001$ & 0.321 & 0.889 \\
\hline Urinary GE output (Mcal/5 d) & 0.96 & 1.01 & 0.95 & 0.94 & 1.03 & 1.09 & 0.28 & 0.609 & 0.724 & 0.938 \\
\hline ME in diet $(\mathrm{kcal} / \mathrm{kg})$ & 3,235 & 3,267 & 3,066 & 3,097 & 3,069 & 3,067 & 79 & $<0.001$ & 0.436 & 0.836 \\
\hline
\end{tabular}

Corn-SBM, corn-soybean meal-based diet; CE, copra expellers 30\% diet; PKE, palm kernel expellers 30\% diet, RMSE, root mean square of error; GE, gross energy; DE, digestible energy; ME, metabolizable energy.

${ }^{1}$ Each least squares mean represents 6 observations.

${ }^{2}$ Feed intake, GE intake, fecal GE output, and urinary GE output were based on $5 \mathrm{~d}$ of collection. 
Table 4. Energy values for copra expellers (CE) and palm kernel expellers (PKE) fed to pigs ${ }^{1}$

\begin{tabular}{|c|c|c|c|c|c|c|c|c|}
\hline \multirow{3}{*}{ Ingredient } & \multicolumn{4}{|c|}{$\beta$-Mannanase (U/kg) } & \multirow{3}{*}{ RMSE } & \multirow{2}{*}{\multicolumn{3}{|c|}{ p-value }} \\
\hline & \multicolumn{2}{|c|}{$\mathrm{CE}$} & \multicolumn{2}{|c|}{ PKE } & & & & \\
\hline & 0 & 2,400 & 0 & 2,400 & & Ingredient & Enzyme & Ingredientxenzyme \\
\hline \multicolumn{9}{|l|}{ As-fed basis } \\
\hline DE (kcal/kg) & 2,873 & 2,879 & 2,905 & 2,851 & 264 & 0.984 & 0.828 & 0.782 \\
\hline $\operatorname{ME}(\mathrm{kcal} / \mathrm{kg})$ & 2,772 & 2,802 & 2,781 & 2,701 & 287 & 0.697 & 0.835 & 0.645 \\
\hline \multicolumn{9}{|l|}{ Dry matter basis } \\
\hline DE (kcal/kg) & 3,238 & 3,246 & 3,137 & 3,079 & 292 & 0.274 & 0.833 & 0.786 \\
\hline $\mathrm{ME}(\mathrm{kcal} / \mathrm{kg})$ & 3,125 & 3,159 & 3,003 & 2,917 & 318 & 0.176 & 0.844 & 0.649 \\
\hline
\end{tabular}

RMSE, root mean square of error; DE, digestible energy; ME, metabolizable energy.

${ }^{1}$ Each least squares mean represents 6 observations.

comparable to those in $\operatorname{PKE}(2,878$ and $2,741 \mathrm{kcal} / \mathrm{kg}$, respectively) regardless of $\beta$-mannanase supplementation.

\section{DISCUSSION}

There are many different factors involved in inhibiting energy and nutrient utilization of feedstuffs by animals. Non-starch polysaccharides are one of the main inhibitors that have negative effects on the digestibility and utilization of nutrients in non-ruminant diets (Choct et al., 2010). Betamannan is a component of NSP and exists as 4 different forms (pure mannan, galactomannan, glucoamannan, and galactoglucomannan) in the cell wall structure of feed ingredients (Sundu et al., 2006). The CE and PKE are rich sources of NSP, and contain relatively high concentration of mannan compared with corn and SBM (Table 1). In the present study, the experimental diets containing $30 \%$ of $\mathrm{CE}$ or PKE were used to test the effect of $\beta$-mannanase supplementation on energy digestibility. Despite that the experimental diets had a large quantity of substrates for the $\beta$-mannanase and considerably high dose of enzyme supplementation $(2,400 \mathrm{U} / \mathrm{kg})$, we failed to find the effects of $\beta$-mannanase supplementation on the energy digestibility of experimental diets. In terms of the corn-SBM basal diet, our results were consistent with a previous study reported by Petty et al. (2002), who demonstrated that there was no difference on DM and energy digestibility in corn-SBMbased diets with $\beta$-mannanase addition. In both studies, a total fecal collection method was used to measure the digestibility of energy and nutrients. On the other hand, results from a recent study suggested that $1,600 \mathrm{U} / \mathrm{kg}$ of $\beta$ mannanase supplementation increased the digestibility of DM, organic matter and energy in a $15 \%$ PKE-containing diet (Mok et al., 2013). Kim et al. (2013) also reported increased DM and energy digestibility in a swine diet containing $5 \%$ of palm kernel meal by $400 \mathrm{U} / \mathrm{kg}$ of $\beta$ mannanase supplementation. Similarly, results of several experiments indicated positive effects of supplemental $\beta$ mannanase on nutrient digestibility in corn-SBM-based diets (Radcliffe et al., 1999; Lv et al., 2013). All these studies that showed positive responses to supplemental $\beta$ mannanase used an index method with chromic oxide as an indigestible index. There is potentially larger variability when the index method is used for digestibility determination compared with a total collection method. A variation in analyzed index concentrations may also cause inaccurate determination of nutrient digestibility. As none of the aforementioned studies reported the analyzed index concentrations, the variability in analyzed index concentrations that may have caused false positive effects of supplemental enzyme on nutrient digestibility is uncertain.

Lower enzyme activity of exogenous carbohydrases in the gastrointestinal tract may be a reason for the lack of effects of the supplemental enzyme on the energy digestibility (Kim et al., 2004). The $\beta$-mannanase (mannanendo-1,4- $\beta$-D-mannosidase, EC 3.2.1.78) product used in this study was an endo-acting carbohydrase, attacking the $1,4-\beta$-D-mannan main chain of the mannan compounds and releasing mannan-oligosaccharides or a small amount of mannose (McCleary, 1988; Kong et al., 2011). However, only mannose belongs to the energy-yielding fraction of mannan metabolites which can be absorbed in the small intestine. In the present study, it is possible that a relatively small quantity of energy-yielding monosaccharide supplied energy to pigs than other experiments. For this reason, although $30 \%$ of mannan-rich ingredients and considerably high dose of enzyme $(2,400 \mathrm{U} / \mathrm{kg})$ were used, we found no effect of $\beta$-mannanase supplementation in this experiment.

The differences in fecal GE output and energy digestibility among diets were mainly due to the $30 \%$ inclusion of PKE or CE which contains greater concentrations of less digestible nutrients such as neutral detergent fiber and acid detergent fiber. Our observations coincide with the data reported by Son et al. (2012). The intake of high-fiber diets has been known to increase passage rate of digesta, which cause reduced digestibility of energy-yielding nutrients (Ravindran et al., 1984; Kim et al., 2007).

The DE and ME contents in CE estimated in the present 
study were less than published data (NRC, 2012). This difference appears to be mainly due to the lower DE:GE ratio measured in the present study compared with NRC (2012) as the GE concentration in CE were comparable to the value in NRC (2012). The DE and ME contents for PKE obtained in this experiment were slightly less than the value reported by NRC (2012), and the DE:GE ratio in PKE was less than that in NRC (2012). However, the ME:DE ratio in PKE in our study was in good agreement with the value in NRC (2012). A recent study reported that the DE values of PKE from Indonesia and PKE from Costa Rica were 3,000 and $2,785 \mathrm{kcal} / \mathrm{kg}$, respectively, and the ME values of PKE from Indonesia and PKE from Costa Rica were 2,891 and $2,681 \mathrm{kcal} / \mathrm{kg}$, respectively (Sulabo et al., 2013). These values are close to our observations.

Clear reasons for the large variation in the DE:GE ratio among sources of CE and PKE are not known; however, it is possible that the different inclusion level of test ingredients may partly contribute to these variations because a low inclusion rate of a test ingredient generally causes a large variability in different procedures. It has been reported that energy digestibility in $\mathrm{CE}$ is largely variable due to the variability in crude protein digestibility (Sulabo et al., 2013). It is also likely that the difference of pigs' body weight may affect energy digestibility in CE and PKE because an improved utilization of fiber with increasing body weight increases the energy digestibility, especially when high-fiber ingredients are used (Noblet, 2007). Moreover, dietary fiber may lower the utilization of other energy-containing nutrients such as crude protein and fat (Noblet and Perez, 1993; Le Goff and Noblet, 2001).

\section{CONCLUSION}

The results obtained in the present study indicate that there was no effect of $\beta$-mannanase supplementation on the $\mathrm{DE}$ and ME values of $\mathrm{CE}$ and PKE fed to pigs.

\section{ACKNOWLEDGMENTS}

The authors are grateful for the support by CTCBIO Inc. (Seoul, Republic of Korea) and National Institute of Animal Science (Rural Development Administration, Republic of Korea; PJ 009340). A part of the present work resulted from the Konkuk University research support program.

\section{REFERENCES}

Agunbiade, J. A., J. Wiseman, and D. J. A. Cole. 1999. Energy and nutrient use of palm kernels, palm kernel meal and palm kernel oil in diets for growing pigs. Anim. Feed Sci. Technol. 80:165181.

AOAC. 2005. Official Methods of Analysis, 18th edn. Association of Official Analytical Chemists, Arlington, VA, USA.
Choct, M., Y. Dersjant-Li, J. McLeish, and M. Peisker. 2010. Soy oligosaccharides and soluble non-starch polysaccharides: A review of digestion, nutritive and anti-nutritive effects in pigs and poultry. Asian Australas. J. Anim. Sci. 23:1386-1398.

Khanongnuch, C., C. Sa-nguansook, and S. Lumyong. 2006. Nutritive quality of $\beta$-mannanase treated copra meal in broiler diets and effectiveness on some fecal bacteria. Int. J. Poult. Sci. 5:1087-1091.

Kil, D. Y., B. G. Kim, and H. H. Stein. 2013. Invited review: Feed energy evaluation for growing pigs. Asian Australas. J. Anim. Sci. 26:1205-1217.

Kim, B. G. and T. M. Kim. 2010. A program for making completely balanced Latin square designs employing a systemic method. Rev. Colomb. Cienc. Pecu. 23:277-282.

Kim, B. G., J. H. Lee, H. J. Jung, Y. K. Han, K. M. Park, and I. K. Han. 2001. Effect of partial replacement of soybean meal with palm kernel meal and copra meal on growth performance, nutrient digestibility and carcass characteristics of finishing pigs. Asian Australas. J. Anim. Sci. 14:821-830.

Kim, B. G., J. Z. Tian, J. S. Lim, D. Y. Kil, H. Y. Jeon, Y. K. Chung, and Y. Y. Kim. 2004. Influences of enzyme complex supplementation on growth, ileal and apparent fecal digestibility and morphology of small intestine in pigs. Asian Australas. J. Anim. Sci. 17:1729-1735.

Kim, B. G., M. D. Lindemann, G. L. Cromwell, A. Balfagon, and J. H. Agudelo. 2007. The correlation between passage rate of digesta and dry matter digestibility in various stages of swine. Livest. Sci. 109:81-84.

Kim, J. S., S. L. Ingale, S. H. Lee, K. H. Kim, J. S. Kim, J. H. Lee, and B. J. Chae. 2013. Effects of energy levels of diet and $\beta$ mannanase supplementation on growth performance, apparent total tract digestibility and blood metabolites in growing pigs. Anim. Feed Sci. Technol. 186:64-70.

Kong, C. and O. Adeola. 2014. Evaluation of amino acid and energy utilization in feedstuff for swine and poultry diets. Asian Australas. J. Anim. Sci. 27:917-925.

Kong, C., J. H. Lee, and O. Adeola. 2011. Supplementation of $\beta$ mannanase to starter and grower diets for broilers. Can. J. Anim. Sci. 91:389-397.

Kratzer, F. H., B. Starcher, and E. W. Martin. 1964. Fractionation of soybean meal for growth and antiperotic factors: 3. Growth promoting activity in benzene soluble fraction. Poult. Sci. 43:663-667.

Le Goff, G. and J. Noblet. 2001. Comparative total tract digestibility of dietary energy and nutrients in growing pigs and adult sows. J. Anim. Sci. 79:2418-2427.

Lv, J. N., Y. Q. Chen, X. J. Guo, X. S. Piao, Y. H. Cao, and B. Dong. 2013. Effects of supplementation of $\beta$-mannanase in corn-soybean meal diets on performance and nutrient digestibility in growing pigs. Asian Australas. J. Anim. Sci. 26:579-587.

McCleary, B. V. 1988. ß-D-mannanase. Meth. Enzymol. 160:596610.

Mok, C. H., J. H. Lee, and B. G. Kim. 2013. Effects of exogenous phytase and $\beta$-mannanase on ileal and total tract digestibility of energy and nutrient in palm kernel expeller-containing diets fed to growing pigs. Anim. Feed Sci. Technol. 186:209-213.

National Research Council. 2012. Nutrient Requirements of Swine. 11th Ed. National Academy Press, Washington DC, USA. 
Noblet, J. 2007. Net energy evaluation of feeds and determination of net energy requirements for pigs. Rev. Bras. Zootec. 36:277284.

Noblet, J. and J. M. Perez. 1993. Prediction of digestibility of nutrients and energy values of pig diets from chemical analysis. J. Anim. Sci. 71:3389-3398.

Pettey, L. A., S. D. Carter, B. W. Senne, and J. A. Shriver. 2002. Effects of beta-mannanase addition to corn-soybean meal diets on growth performance, carcass traits, and nutrient digestibility of weanling and growing-finishing pigs. J. Anim. Sci. 80:1012-1019.

Radcliffe, J. S., B. C. Robbins, J. P. Rice, R. S. Pleasant, and E. T. Kornegay. 1999. The effects of Hemicell ${ }^{\circledR}$ on digestibilities of minerals, energy, and amino acids in pigs fitted with steered ileo-cecal valve cannulas and fed a low and high protein cornsoybean meal diet. J. Anim. Sci. 77 (supple. 1):197 (Abstr.).

Rainbird, A. L., A. G. Low, and T. Zebrowska. 1984. Effect of guar gum on glucose and water absorption from isolated loops of jejunum in conscious growing pigs. Br. J. Nutr. 52:489-498.

Ravindran, V., E. T. Kornegay, and K. E. Webb, Jr. 1984. Effects of fiber and virginiamycin on nutrient absorption, nutrient retention and rate of passage in growing swine. J. Anim. Sci. 59:400-408.
Son, A. R., S. Y. Ji, and B. G. Kim. 2012. Digestible and metabolizable energy concentrations in copra meal, palm kernel meal, and cassava root fed to growing pigs. J. Anim. Sci. 90:140-142.

Sulabo, R. C., W. S. Ju, and H. H. Stein. 2013. Amino acid digestibility and concentration of digestible and metabolizable energy in copra meal, palm kernel expellers, and palm kernel meal fed to growing pigs. J. Anim. Sci. 91:1391-1399.

Sundu, B., A. Kumar, and J. Dingle. 2006. Palm kernel meal in broiler diets: effect on chicken performance and health. World's Poult. Sci. J. 62:316-325.

Yin, Y. -L., J. D. G. McEvoy, H. Schulze, U. Henning, W. -B. Souffrant, and K. J. McCracken. 2000. Apparent digestibility (ileal and overall) of nutrients and endogenous nitrogen losses in growing pigs fed wheat (var. Soissons) or its by-products without or with xylanase supplementation. Livest. Prod. Sci. 62:119-132.

Yin, Y. -L., S. K. Baidoo, L. Z. Jin, Y. G. Liu, H. Schulze, and P. H. Simmins. 2001. The effect of different carbohydrase and protease supplementation on apparent (ileal and overall) digestibility of nutrients of five hulless barley varieties in young pigs. Livest. Prod. Sci. 71:109-120. 